\title{
Seasonal variability of surface and column carbon monoxide over the megacity Paris, high-altitude Jungfraujoch and Southern Hemispheric Wollongong stations
}

\author{
Yao Té ${ }^{1}$, Pascal Jeseck ${ }^{1}$, Bruno Franco ${ }^{2}$, Emmanuel Mahieu ${ }^{2}$, Nicholas Jones ${ }^{3}$, Clare Paton-Walsh ${ }^{3}$, \\ David W. T. Griffith ${ }^{3}$, Rebecca R. Buchholz ${ }^{4}$, Juliette Hadji-Lazaro ${ }^{5}$, Daniel Hurtmans ${ }^{6}$, and Christof Janssen ${ }^{1}$ \\ ${ }^{1}$ LERMA-IPSL, Sorbonne Universités, UPMC Univ Paris 06, CNRS, Observatoire de Paris, \\ PSL Research University, 75005, Paris, France \\ ${ }^{2}$ Institut d'Astrophysique et de Géophysique, Université de Liège, 4000 Liège, Belgium \\ ${ }^{3}$ Center for Atmospheric Chemistry, Faculty of Science, Medicine \& Health, University of Wollongong, \\ Wollongong, NSW 2522 Australia \\ ${ }^{4}$ Atmospheric Chemistry Observations \& Modelling Laboratory, National Center for Atmospheric Research, \\ Boulder, CO, USA \\ ${ }^{5}$ Sorbonne Universités, UPMC Univ. Paris 06, Univ. Versailles St-Quentin, CNRS/INSU, \\ UMR 8190, LATMOS-IPSL, Paris, France \\ ${ }^{6}$ Spectroscopie de l'Atmosphère, Service de Chimie Quantique et Photophysique, \\ Université Libre de Bruxelles, Brussels, Belgium
}

Correspondence to: Yao Té (yao-veng.te@upmc.fr)

Received: 28 October 2015 - Published in Atmos. Chem. Phys. Discuss.: 8 March 2016

Revised: 15 June 2016 - Accepted: 14 July 2016 - Published: 5 September 2016

\begin{abstract}
This paper studies the seasonal variation of surface and column CO at three different sites (Paris, Jungfraujoch and Wollongong), with an emphasis on establishing a link between the $\mathrm{CO}$ vertical distribution and the nature of $\mathrm{CO}$ emission sources. We find the first evidence of a time lag between surface and free tropospheric $\mathrm{CO}$ seasonal variations in the Northern Hemisphere. The CO seasonal variability obtained from the total columns and free tropospheric partial columns shows a maximum around March-April and a minimum around September-October in the Northern Hemisphere (Paris and Jungfraujoch). In the Southern Hemisphere (Wollongong) this seasonal variability is shifted by about 6 months. Satellite observations by the IASI-MetOp (Infrared Atmospheric Sounding Interferometer) and MOPITT (Measurements Of Pollution In The Troposphere) instruments confirm this seasonality. Ground-based FTIR (Fourier transform infrared) measurements provide useful complementary information due to good sensitivity in the boundary layer. In situ surface measurements of $\mathrm{CO}$ volume mixing ratios at the Paris and Jungfraujoch sites reveal a time
\end{abstract}

lag of the near-surface seasonal variability of about 2 months with respect to the total column variability at the same sites. The chemical transport model GEOS-Chem (Goddard Earth Observing System chemical transport model) is employed to interpret our observations. GEOS-Chem sensitivity runs identify the emission sources influencing the seasonal variation of CO. At both Paris and Jungfraujoch, the surface seasonality is mainly driven by anthropogenic emissions, while the total column seasonality is also controlled by air masses transported from distant sources. At Wollongong, where the $\mathrm{CO}$ seasonality is mainly affected by biomass burning, no time shift is observed between surface measurements and total column data.

\section{Introduction}

Atmospheric carbon monoxide (CO) is an important trace gas. It has direct and indirect impacts on air quality due to its toxicity and its effect on the atmospheric oxidising ca- 
pacity. The major sources of $\mathrm{CO}$ are fuel and energy-related industries, heating, motor vehicle transport, biomass burning and the secondary oxidation of methane and volatile organic compounds (VOCs such as isoprene and terpene, which are emitted by plants). Due to the fast reaction

$\mathrm{CO}+\mathrm{OH} \rightarrow \mathrm{CO}_{2}+\mathrm{H}$,

$\mathrm{CO}$ is the major sink for the main atmospheric oxidation agent, the hydroxyl radical OH (Weinstock, 1969; Bakwin et al., 1994). A global increase of atmospheric CO thus leads to a decrease in global $\mathrm{OH}$, which in turn augments the concentration of other potentially harmful atmospheric trace gases (Logan et al., 1981; Thompson et al., 1990; Thompson, 1992) or potent greenhouse gases sensitive to oxidation such as methane, which contributes about one-third to the total sources of CO (Duncan et al., 2007; Holloway et al., 2000). The limited measurements before 1980 showed an increase of $\mathrm{CO}$ in the Northern Hemisphere (Khalil and Rasmussen, 1988; Zander et al., 1989), probably related to an increase of anthropogenic emissions (Novelli et al., 1998). From the end of 1980 to 1997, atmospheric CO decreased (Khalil and Rasmussen, 1994; Novelli et al., 1994). Since then, a few large episodic increases of $\mathrm{CO}$, associated with unusually large forest fires, have been observed in the Northern Hemisphere (Novelli et al., 2003; Yurganov et al., 2004, 2005). Bekki et al. (1994) have observed a negative trend in CO, that was attributed to the Mount Pinatubo eruption in June 1991. In the Southern Hemisphere no significant trends were observed (Brunke et al., 1990; Novelli et al., 2003). Global observations of $\mathrm{CO}$ began with the start of the flask sampling programme of the NOAA ${ }^{1}$ Earth System Research Laboratory, Global Monitoring Division (Novelli et al., 1994, 1998, 2003). In parallel, CO total column observations were performed at several locations (Mahieu et al., 1997; Zhao et al., 1997; Rinsland et al., 1998, 1999, 2000).

This paper characterises the $\mathrm{CO}$ seasonal variability at three ground-based FTIR (Fourier transform infrared) sites: the megacity Paris, high-altitude Jungfraujoch and Southern Hemisphere Wollongong. These sites have been selected for their representativeness of different environments (remote vs. moderate and high pollution sites, Northern vs. Southern Hemisphere) and meteorological conditions.

- The megacity of Paris (France): a high-resolution Fourier transform spectrometer from Bruker IFS 125HR (FTS-Paris) was installed in 2006 on the campus of Université Pierre et Marie Curie in the centre of the French capital Paris $\left(48^{\circ} 50^{\prime} 47^{\prime \prime} \mathrm{N}, 2^{\circ} 21^{\prime} 21^{\prime \prime} \mathrm{E}, 60 \mathrm{~m}\right.$ a.s.l.). Since then, the instrument has been continuously operated by LERMA ${ }^{2}$.

\footnotetext{
${ }^{1}$ National Oceanic and Atmospheric Administration

${ }^{2}$ Laboratoire d'Études du Rayonnement et de la Matière en Astrophysique et Atmosphères
}

- Jungfraujoch (Switzerland): the International Scientific Station of the Jungfraujoch (ISSJ) is located in the Swiss Alps $\left(46^{\circ} 33^{\prime} \mathrm{N}, 7^{\circ} 58^{\prime} 48^{\prime \prime} \mathrm{E}, 3580 \mathrm{~m}\right.$ a.s.1.). Two FTIR instruments have been used at that site, a homemade FTIR from 1984 to 2008 and a commercial Bruker IFS 120 HR from the early 1990 to present. The University of Liège (Belgium) is responsible for the operation of the infrared instruments at Jungfraujoch.

- Wollongong (Australia): the station is located in the Southern Hemisphere at Wollongong University $\left(34^{\circ} 24^{\prime} 22^{\prime \prime} \mathrm{S}, 150^{\circ} 52^{\prime} 44^{\prime \prime} \mathrm{E}, 30 \mathrm{~m}\right.$ a.s.l.). The instrument, which is also a commercial high-resolution Fourier transform spectrometer (Bruker IFS 125HR), is operated by the University of Wollongong and has provided data since 1996.

All three ground-based FTIR spectrometers are part of NDACC (Network for the Detection of Atmospheric Composition Change) and/or TCCON (Total Carbon Column Observing Network) networks and have monitored the concentration of $\mathrm{CO}$ for several years. Paris is the first ground-based FTIR station located in a European megacity which provides rare hotspot measurements of atmospheric species related to anthropogenic activities. The remote high-altitude Jungfraujoch station provides one of the longest observational time series for a variety of atmospheric gases. Wollongong is a station exposed to moderate levels of pollution and is located on the east coast of Australia, about $80 \mathrm{~km}$ from the south of Sydney. Here, we analyse NDACC data for the seasonal variations of $\mathrm{CO}$ and compare the results from the different sites. The ground-based remote sensing measurements are compared with results from the satellite instruments IASI-MetOp (infrared atmospheric sounding interferometer; Tournier et al., 2002) and MOPITT (Measurements Of Pollution In The Troposphere; Drummond and Mand, 1996). With respect to satellite measurements, ground-based FTIR instruments are more sensitive to the boundary layer and can therefore provide complementary information which we compare with in situ measurements at the surface. Due to specific conditions at the ground, the surface and the total column seasonalities might differ from each other. Using GEOS-Chem modelling (Goddard Earth Observing System chemical transport model, CTM; Bey et al., 2001) simulations, we investigate the impact of local sources on the lower partial column and its variability compared to the total column.

The paper is structured as follows. In Sect. 2, the remote sensing instruments and measurements are described. Section 3 presents the in situ analyser measurements and the GEOS-Chem model simulation data. Section 4 shows the CO total column variability obtained from both the remote sensing data and the surface in situ measurements. Both results are compared to the GEOS-Chem model simulations, which are also used to identify emission sources at each site. 
Table 1. Ground-based FTIR instrument parameters for the three measurement stations.

\begin{tabular}{|c|c|c|c|}
\hline & Paris & Jungfraujoch & Wollongong \\
\hline Sun tracker model & A547 (Bruker Optics) & Homemade & A547 (Bruker Optics) \\
\hline Sun tracker accuracy & $<1$ arcmin & $<6 \operatorname{arcmin}$ & $<1$ arcmin \\
\hline Spectrometer & IFS $125 \mathrm{HR}$ & IFS $120 \mathrm{HR}$ & IFS $125 \mathrm{HR}$ \\
\hline Network & TCCON with NDACC measurements & NDACC & NDACC and TCCON \\
\hline Optical Path Difference & $257 \mathrm{~cm}$ & 114 to $175 \mathrm{~cm}$ & $257 \mathrm{~cm}$ \\
\hline Integration time & $\begin{array}{l}205 \mathrm{~s} \\
(2 \text { coadditions })\end{array}$ & $\begin{array}{l}135 \text { to } 1035 \mathrm{~s} \\
\text { (depending on coaddition and OPD) }\end{array}$ & $\begin{array}{l}206 \mathrm{~s} \\
(2 \text { coadditions })\end{array}$ \\
\hline Entrance window & $\begin{array}{l}\mathrm{CaF}_{2} \\
\text { (instrument under vacuum) }\end{array}$ & $\begin{array}{l}\text { None } \\
\text { (instrument not under vacuum) }\end{array}$ & $\begin{array}{l}\mathrm{KBr} \\
\text { (instrument under vacuum) }\end{array}$ \\
\hline Beam splitter & $\mathrm{CaF}_{2}$ & $\mathrm{KBr}$ & $\mathrm{CaF}_{2}$ \\
\hline Optical filter & Yes & Yes & Yes \\
\hline Detector & $\mathrm{InSb}$ & $\mathrm{InSb}$ & $\mathrm{InSb}$ \\
\hline Spectral range & 3.8 to $5.1 \mu \mathrm{m}$ & 4.4 to $6 \mu \mathrm{m}$ & 4.4 to $5.1 \mu \mathrm{m}$ \\
\hline
\end{tabular}

\section{Remote sensing instruments and measurements}

\subsection{Instrumentation and measurements at Paris, France}

The FTS-Paris is a Michelson interferometer from Bruker Optics. Table 1 lists technical details for the ground-based FTIR instruments as well as the configuration used for the measurements. Solar absorption spectra are acquired by coupling the FTS to a sun tracker installed on the roof terrace. The solar disk is tracked with an accuracy of less than 1 arcmin. Appropriate band pass filters allows the optimisation of the signal-to-noise ratio when focussing on specific target gases. The Paris instrument is part of TCCON (TCCON-Paris station). For this CO study, the FTS-Paris uses optical elements corresponding to a typical NDACC configuration. More instrumental details and different measurement configurations are given elsewhere (Té et al., 2010, 2012).

Only clear-sky spectra were analysed. Available solar spectra cover the time period from May 2009 to the end of 2013, with only very few spectra (about 400 spectra during 19 measurement days) for the period between 2009 and 2010. Between 2011 and 2013, spectra acquisition was more frequent, and more than 4500 spectra from 117 measurement days were recorded and analysed. The absorption lines of each atmospheric species observed in the solar spectra are used to retrieve its abundance in the atmosphere by appropriate radiative transfer and inversion algorithms (Pougatchev and Rinsland, 1995; Zhao et al., 1997; Hase et al., 2006). We have used the PROFFIT (profile fit) algorithm developed by F. Hase to analyse the Paris data using the HITRAN 2008 spectral database (Rothman et al., 2009). PROFFIT is a code especially adapted for the analysis of solar absorption spectra from the ground and it has been widely applied and tested (Hase et al., 2004; Duchatelet et al., 2010; Schneider et al., 2010; Té et al., 2012; Viatte et al., 2011). For the retrieval of $\mathrm{CO}$, we have selected two microwindows. The 2110.4$2110.5 \mathrm{~cm}^{-1}$ microwindow is centred around the weak $R(3)$ line of ${ }^{13} \mathrm{CO}$, which is more sensitive to $\mathrm{CO}$ at higher altitudes and the $2111.1-2112.1 \mathrm{~cm}^{-1}$ microwindow around the strongly saturated $P(8)$ line of ${ }^{12} \mathrm{CO}$. The left and right wings of the $P(8)$ line are particularly sensitive to $\mathrm{CO}$ in the planetary boundary layer (PBL). The retrieval uses a grid with 49 altitude levels and, on average, there are about 2.7 degrees of freedom for signal (DOFS). The uncertainties in the $\mathrm{CO}$ column density and the profile stem from a variety of sources. These sources have been investigated in detail by Té et al. (2012), following the procedure outlined by Rinsland et al. (2000). According to this evaluation, the random uncertainty is around $2.5 \%$. Concerning the systematic uncertainties of about 3 to $6.8 \%$ (Té et al., 2012), the largest source is linked to the quality of available spectroscopic parameters (line intensity and air-broadened half-width uncertainties in Rothman et al., 2009), which is similar for the three sites.

\subsection{Instrumentation and measurements at Jungfraujoch, Switzerland}

The Jungfraujoch station in Switzerland is part of NDACC and the instrumental set-up is similar to the one in Paris, cf. Table 1. A thorough description of the instrumentation is given by Zander et al. (2008). Infrared solar spectra are recorded under clear-sky conditions and, due to the high altitude, the interference by water vapour is very low. The integration time is either 135,404 or $1035 \mathrm{~s}$, corresponding to 3 or 9 scans of $45 \mathrm{~s}$ or 15 scans of $69 \mathrm{~s}$. High-resolution observations are only recorded under slowly varying geometry, i.e. for zenith angles lower than $\sim 70^{\circ}$.

The Jungfraujoch data set corresponds to an update of the CO time series described by Dils et al. (2011). It covers the January 2009 to December 2013 time period and includes 1733 individual spectra recorded on 539 different days. Mean signal-to-noise ratio $(S / N)$ is 2930 , with the 2 nd percentile 
still being above 1000. The SFIT-2 (v3.91) algorithm (Rinsland et al., 1998) based on the semi-empirical implementation of the optimal estimation method (OEM) of Rodgers (1990) is used, allowing retrieval of information on the vertical profile of most FTIR target gases. The standard NDACC approach for the $\mathrm{CO}$ retrieval is adopted to simultaneously fit three microwindows spanning the 2057.7-2058.0, 2069.562069.76 and $2157.3-2159.15 \mathrm{~cm}^{-1}$ intervals. The line parameters correspond to the standard release of HITRAN 2004 (Rothman et al., 2005), including the August 2006 updates (e.g. Esposito et al., 2007). The a priori mixing ratio profiles for all interfering molecules (main telluric absorptions by $\mathrm{N}_{2} \mathrm{O}, \mathrm{O}_{3}, \mathrm{H}_{2} \mathrm{O}$ and $\mathrm{CO}_{2}$ ) correspond to a mean of the 19752020 version 4 WACCM model (the Whole Atmosphere Community Climate Model; https://www2.cesm.ucar.edu/ working-groups/wawg) simulation performed for Jungfraujoch. The $\mathrm{CO}$ a priori vertical distribution combines version 4 WACCM results above $15.5 \mathrm{~km}$, ACE-FTS (Atmospheric Chemistry Experiment - Fourier transform spectrometer) occultation measurements between 6.5 and $15.5 \mathrm{~km}$ (version 2.2, Clerbaux et al., 2008) and extrapolation of ACE-FTS data down to the station altitude, ending at $137 \mathrm{ppbv}$ in the first retrieval layer $(3.58-4.23 \mathrm{~km})$. Additional retrieval settings include a $S / N$ ratio of 150 for inversion, the a priori covariance matrix, with diagonal elements close to $30 \% \mathrm{~km}^{-1}$ in the troposphere and extradiagonal elements computed assuming a Gaussian interlayer correlation half-width length of $4 \mathrm{~km}$. Objective evaluation of the resulting typical information content indicates that two independent pieces of information are available (DOFS of 2.2 on average). Typical random uncertainties have been evaluated at $2-3 \%$ for the total columns and $5 \%$ for the $3.58-7.18 \mathrm{~km}$ partial columns.

\subsection{Instrumentation and measurements at Wollongong, Australia}

The Wollongong instrument is part of both NDACC and TCCON. The instrument set-up is similar to the Paris and Jungfraujoch spectrometers (see Table 1). Using the NDACC configuration, $\mathrm{CO}$ total and partial column data are produced using three microwindows in the $4.6 \mu \mathrm{m}$ band of CO (Zeng et al., 2015).

The analysis of the Wollongong NDACC data is very similar to the method described in Sect. 2.2 for the Jungfraujoch data. The algorithm used was SFIT4 v9.4.4 (https://wiki.ucar.edu/display/sfit4/Infrared+ Working+Group+Retrieval+Code,+SFIT), an updated version of SFIT2 used in the Jungfraujoch analysis. SFIT4 has inherited the same forward model and inverse method but with a number of enhancements (not required in the $\mathrm{CO}$ analysis) and gives the same results in the $\mathrm{CO}$ retrieval. For the Wollongong data, HITRAN 2008 was adopted (Rothman et al., 2009), the mean of the 1980-2020 WACCM version 4 run used as the a priori CO profile (and a $4 \mathrm{~km}$ Gaussian interlayer correlation), with the a priori covariance matrix set to 1 standard deviation of the WACCM profiles. A measurement signal-to-noise ratio of 200 was assumed. This gives a mean DOFS of 2.7. The version 4 WACCM profiles were also used for the a priori profiles of all actively fitted interfering gases $\left(\mathrm{O}_{3}, \mathrm{H}_{2} \mathrm{O}, \mathrm{N}_{2} \mathrm{O}, \mathrm{CO}_{2}\right.$, etc.). The error analysis used a NDACC community Python tool to estimate errors assuming a solar zenith angle of $50.2^{\circ}$, representing the mean zenith angle for all Wollongong spectra. The resulting $\mathrm{CO}$ total column random errors were calculated to be $2.2 \%$.

\subsection{Satellite instruments and measurements}

The IASI Michelson interferometer (Infrared Atmospheric Sounding Interferometer; Tournier et al., 2002; Blumstein et al., 2004) is on board the meteorological operation (MetOp) polar orbiting platform. The first platform (MetOpA) was launched on 19 October 2006 and operational data have been provided since October 2007. IASI operates at an altitude of around $817 \mathrm{~km}$ on a sun-synchronous orbit with a $98.7^{\circ}$ inclination to the equator. It overpasses each region twice a day. The MetOp platform has a swath of 30 views of $50 \mathrm{~km}$ by $50 \mathrm{~km}$ comprising four off-axis pixels of $12 \mathrm{~km}$ diameter footprint each at nadir. A second platform (MetOp-B) was launched in September 2012 and the launch of the third and last platform (MetOp-C) is scheduled for October 2018. IASI observations provide an important contribution to the monitoring of atmospheric composition over time (Clerbaux et al., 2009).

The IASI-MetOp is a Fourier transform spectrometer with a medium spectral resolution of $0.5 \mathrm{~cm}^{-1}$ and a radiometric noise of about $0.2 \mathrm{~K}$ at $280 \mathrm{~K}$ using nadir viewing and working in the thermal infrared (TIR) range extending from 645 to $2760 \mathrm{~cm}^{-1}$ with no gaps. The CO products (L2) are downloaded from the ETHER database for the period from 1 January 2009 to 31 December 2013 (Clerbeaux, 2014). The total column data were generated from the IASI radiance spectra in the $4.7 \mu \mathrm{m}$ spectral range and from meteorological data (surface and vertical profile of temperature, humidity vertical profile and cloud cover) (August et al., 2012), using the Fast Optimal Retrievals on Layers for IASI (FORLI) code (Hurtmans et al., 2006). The CO total columns were compared to other CO satellite data (George et al., 2009), from which a DOFS value of about 2 was provided and a relative uncertainty between 4 and $10 \%$ could be estimated. The total columns are calculated from the ground altitude to $60 \mathrm{~km}$ height. For this paper, we also provide additional vertical volume mixing ratio (VMR) profiles and partial columns in the PBL and in the troposphere layers around Île-de-France, as well as the partial columns above $4 \mathrm{~km}$ height around the Jungfraujoch site.

The MOPITT instrument (Drummond and Mand, 1996; Deeter et al., 2004) is on board NASA's Terra spacecraft in a sun-synchronous polar orbit at an altitude of $705 \mathrm{~km}$. The satellite was launched on 18 December 1999. MOPITT has been in operation since March 2000. The instrument uses the 
technique of gas-filter correlation radiometry based on the IR absorption bands of $\mathrm{CO}$ to retrieve the vertical profiles of CO. The horizontal footprint of each MOPITT retrieval is $22 \mathrm{~km}$ by $22 \mathrm{~km}$.

The MOPITT data were downloaded from the NASA website (Deeter et al., 2014). We are using version 6 retrievals of $\mathrm{CO}$ vertical profiles and total columns, for the period from the beginning of 2009 to the end of 2013. Since version 5 of the MOPITT retrieval algorithm, TIR $(4.7 \mu \mathrm{m})$ radiances are combined with the near IR $(2.3 \mu \mathrm{m})$ daily radiances to improve the sensitivity to lower tropospheric CO over land. The DOFS value is about 2 (Worden et al., 2010). The retrieved vertical VMR profile is reported at 10 pressure levels (at the surface and every hundred $\mathrm{hPa}$ between 900 and $100 \mathrm{hPa}$ ). The retrieved $\mathrm{CO}$ total columns are obtained by integrating the retrieved VMR profile. In this paper, we are using the level 2 TIR/NIR products.

The following precautions have been taken in order to improve comparability between satellite and ground-based measurements.

- Only clear-sky data from ground-based FTIR and satellites has been used.

- The CO abundance is retrieved from the same spectral domain $(4.7 \mu \mathrm{m}$ for both the ground-based FTIR and the satellite instruments), allowing minimisation of possible biases related to spectroscopic parameters and interfering atmospheric constituents (gaseous species, aerosols).

- Satellite data were selected within a range of $\pm 0.15^{\circ}$ for the latitude and $\pm 0.23^{\circ}$ for the longitude, corresponding to a $33 \mathrm{~km} \times 33 \mathrm{~km}$ square centred at the Paris site.

\section{In situ analyser measurements and GEOS-Chem model simulation data}

\subsection{Surface in situ measurements at Paris}

Continuous in situ measurements of the CO surface concentration are performed using a commercial analyser (CO11M, Environnement SA). The operating principle of the $\mathrm{CO}$ analyser is based on the $\mathrm{CO}$ infrared absorption at $4.67 \mu \mathrm{m}$, which is the same spectral band covered by the FTS-Paris. Ambient atmospheric air is drawn from the building rooftop into the analyser via PTFE tubing using a diaphragm pump, which is limited to a gas flow of $80 \mathrm{~L} \mathrm{~h}^{-1}$. The pumped air is analysed in a $20 \mathrm{~cm}$-length multipath absorption cell with an absorption path length of $5.6 \mathrm{~m}$, using a globar as IR light source and a photoconductive $\mathrm{PbSe}$ detector. The $\mathrm{CO}$ analyser has a sensitive range between 0.1 and 200 ppmv, with an uncertainty of $50 \mathrm{ppbv}$ for each individual measurement. Recorded values are time averages over $15 \mathrm{~min}$. For the present paper, daily in situ surface $\mathrm{CO}$ measurements are available for the whole period between the beginning of 2009 and end of 2013.

\subsection{Surface in situ measurements in Switzerland}

Swiss in situ surface data are from the Swiss National Air Pollution Monitoring Network (NABEL), which is a network of 16 observation sites distributed throughout Switzerland in order to measure and record long-term measurement series of air pollutants. The NABEL monitoring network is operated by EMPA. The monitoring stations are representative of different pollution levels. The monthly averaged data were obtained from the annual reports published by the Swiss OFEV (Office Fédéral de l'Environnement; Ballamann, 2014). In this paper, we have focussed on the urban sites Bern, Lausanne, Lugano and Zürich, as well as the remote mountain station of Jungfraujoch.

\subsection{Surface in situ measurements at Wollongong}

Surface $\mathrm{CO}$ at Wollongong is measured using two highprecision in situ FTIR trace gas analysers (Griffith et al., 2012). The analysers use an IR source, modulated through a Michelson interferometer with a $\mathrm{CaF}_{2}$ beam splitter. The modulated IR beam is passed through a dried atmospheric sample within a White cell in a $24 \mathrm{~m}$ folded path and subsequently detected by thermoelectrically cooled MCT (Mercury Cadmium Telluride) detector. Ambient air is measured daily over $23.5 \mathrm{~h}$, with $30 \mathrm{~min}$ reserved for calibration using constant composition air. Ambient air is flushed through an inlet line at $5 \mathrm{~L} \mathrm{~min}^{-1}$ and sample air is continuously drawn from this line through the instrument at $1 \mathrm{~L} \mathrm{~min}^{-1}$. The SpectronusTM software (Ecotech P/L, Knoxfield, VIC, Australia) is used to automate internal valve control and stabilise parameters, such as flow, pressure and temperature. Recorded spectra are averaged over $3 \mathrm{~min}$. Non-linear least-squares fitting of $\mathrm{CO}$ occurs in two broad spectral regions (from 4.33 to $4.65 \mu \mathrm{m}$ and 4.46 to $4.76 \mu \mathrm{m}$ ), using the programme MALT (Multiple Atmospheric Layer Transmission, Griffith (1996)). Data are reported as dry-air mole fraction, with a total relative measurement uncertainty below $1 \%$. Wollongong $\mathrm{CO}$ measurements were first analysed by Buchholz et al. (2016a, b) and are publicly available as $10 \mathrm{~min}$ averages. For this paper, in situ data are monthly averaged and selected to cover the period from June 2012 to May 2013.

\subsection{Data from the GEOS-Chem model}

The global 3-D chemical transport model GEOS-Chem (version 9-02: http://acmg.seas.harvard.edu/geos/doc/archive/ man.v9-02) can be used to simulate global trace gas (more than 100 tracers) and aerosol distributions. The model is driven by the Goddard Earth Observing System v5 (GEOS5) assimilated meteorological fields from the NASA Global Modelling Assimilation Office (GMAO), which are at a native horizontal resolution of $0.5^{\circ} \times 0.667^{\circ}$. The GEOS-5 data 
describe the atmosphere from the surface up to $0.01 \mathrm{hPa}$ with 72 hybrid pressure- $\sigma$ levels, at a $6 \mathrm{~h}$ temporal frequency $(3 \mathrm{~h}$ for surface properties and mixing depths). In this study, we use the degraded GEOS-5 meteorological fields as model input to a $2^{\circ} \times 2.5^{\circ}$ horizontal resolution and 47 vertical levels, lumping together levels above $\sim 80 \mathrm{hPa}$. We apply here the standard full chemistry GEOS-Chem simulation, including detailed $\mathrm{O}_{3}-\mathrm{NO}_{x}$ - volatile organic compound (VOC) aerosol coupled chemistry (Bey et al., 2001; Park et al., 2004; with updates by Mao et al., 2010).

Tropospheric $\mathrm{CO}$ is sourced from anthropogenic, biomass burning and biofuel burning emissions, as well as from the degradation of many VOCs. The emission inventory of the Emissions Database for Global Atmospheric Research (EDGAR; http://edgar.jrc.ec.europa.eu) v3.2 (Olivier and Berdowski, 2001) is the global reference for anthropogenic emissions of $\mathrm{CO}, \mathrm{NO}_{x}, \mathrm{SO}_{x}$ and $\mathrm{NH}_{3}$. For global anthropogenic sources of non-methane VOCs (NMVOCs), GEOSChem uses the REanalysis of the TROpospheric chemical composition (RETRO; http://gcmd.gsfc.nasa.gov/records/ GCMD_GEIA_RETRO) emission inventory (Schultz et al., 2007 ) for the base year 2000. However, these global inventories may be overwritten by regional emission inventories such as over Europe, where the anthropogenic emissions of $\mathrm{CO}, \mathrm{NO}_{x}, \mathrm{SO}_{x}, \mathrm{NH}_{3}$, propene, acetaldehyde, methyl ethyl ketone and higher $\mathrm{C} 3$ alkanes are provided by the European Monitoring and Evaluation Programme (EMEP; http: //www.ceip.at) regional inventory for the year 2010 (Benedictow et al., 2010). All these global and regional inventories are scaled to the years of interest according to the method described by van Donkelaar et al. (2008). Anthropogenic sources of ethane and propane are derived from an offline simulation (Xiao et al., 2008). The global biomass burning emissions are provided by the Global Fire Emissions Database (GFED) v3 (van der Werf et al., 2010) and the global biogenic emissions are obtained with the Model of Emissions of Gases and Aerosols from Nature (MEGAN) v2.1 (Guenther et al., 2006). Methane concentrations in GEOS-Chem are based on measurements from the NOAA Global Monitoring Division flask measurements.

The GEOS-Chem data set employed in the present work covers the period from January 2009 to May 2013 and is derived from a July 2005 to May 2013 simulation, for which the GEOS-5 meteorological fields are available. A 1-year run preceding this simulation was used for chemical initialisation of the model. The model outputs consist of CO VMR profiles simulated at the closest pixel to each station and saved at a $3 \mathrm{~h}$ time step. The vertical resolution and the sensitivity of the FTIR retrievals have been taken into account for the comparisons involving GEOS-Chem results: the individual VMR profiles produced by the model have been first regridded onto the vertical layer scheme adopted at each station, then daily averaged and finally smoothed by convolution with the FTIR averaging kernels (AVKs) according to the formalism of Rodgers and Connor (2003). The regrid- ding method used here is a mass conservative interpolation that preserves the $\mathrm{CO}$ total mass simulated above the altitude of the station (the CO mass below is ignored). The AVKs employed for smoothing are seasonal averages (over MarchMay, June-August, September-November and DecemberFebruary) derived from the individual retrievals of the 20092013 FTIR data sets. The smoothing did not change the comparison results between the model and our observations (difference smaller than $1 \%$ ).

\section{Seasonal variability}

\subsection{Remote sensing observations}

Figure 1 shows the CO total columns of the three groundbased FTIR sites from 2009 to the end of 2013. The data from Paris are less numerous than from the other two sites, because measurements are not fully automated and spectral acquisitions are only launched when clear sky is expected for more than half of the daytime. Moreover, from 2009 to 2010, Paris CO spectra were recorded only during intensive measurement campaigns, and not on a regular basis. As expected, the $\mathrm{CO}$ abundance is higher in the Northern Hemisphere. The $\mathrm{CO}$ column mean value is about $2.1 \times 10^{18}$ molecules $\mathrm{cm}^{-2}$ at the Paris station which is almost twice as high as the value at Wollongong $\left(1.3 \times 10^{18}\right.$ molecules $\left.\mathrm{cm}^{-2}\right)$. The $\mathrm{CO}$ column mean value of $1.1 \times 10^{18}$ molecules $\mathrm{cm}^{-2}$ at the Jungfraujoch station is quite low and is attributed to the site's height.

All three sites clearly display a seasonal variability of $\mathrm{CO}$. We have used a sine function to characterise seasonality (Eq. 1). This is in agreement with previous studies conducted by Rinsland et al. (2000, 2001, 2007) and Zhao et al. (2002), but in comparison to Rinsland et al. (2000, 2001, 2007), we have removed the linear term, because our data sets do not show any significant trend:

$y=y_{0}+A \sin \left(\pi \frac{t-t_{c}}{w}\right)$,

where $y$ represents the abundance of $\mathrm{CO}$ (in total or partial columns or volume mixing ratio), $y_{0}$ is the mean value (offset), $A$ and $w$ are respectively the amplitude and half-period of the seasonal cycle, $t$ and $t_{c}$ the date and the phase shift. Table 2 summarises the fit results for $w$ and $A$ obtained at the three sites.

For the Northern Hemisphere (Paris and Jungfraujoch) stations, the maximum is observed around March-April and the minimum around September-October. The average amplitude of the seasonal variability is about $(13 \pm 3) \%$ of the column average and the average half cycle is about $188 \pm 4$ days for both Northern Hemispheric sites. For Paris, the value $w=191 \pm 3$ days is slightly, but not significantly, higher than at Jungfraujoch, probably due to the lack of data before 2011. This seasonal variability is also observed by Rinsland et al. (2007) at Kitt Peak, which is the US National 
Table 2. Parameters obtained from the sinusoidal fit of the seasonal variability to the CO total columns from ground-based, satellite and GEOS-Chem modelling data.

\begin{tabular}{|c|c|c|c|c|c|c|}
\hline & \multicolumn{2}{|c|}{ Paris } & \multicolumn{2}{|c|}{ Jungfraujoch } & \multicolumn{2}{|c|}{ Wollongong } \\
\hline & $\begin{array}{r}\text { Half-period }(w) \\
(\text { days })\end{array}$ & $\begin{array}{r}\text { Amplitude }(A) \\
(\%)\end{array}$ & $\begin{array}{r}\text { Half-period }(w) \\
(\text { days })\end{array}$ & $\begin{array}{r}\text { Amplitude }(A) \\
(\%)\end{array}$ & $\begin{array}{r}\text { Half-period }(w) \\
(\text { days })\end{array}$ & $\begin{array}{r}\text { Amplitude }(A) \\
(\%)\end{array}$ \\
\hline Ground-based & $191 \pm 3$ & $14 \pm 1$ & $185 \pm 1$ & $12 \pm 1$ & $178 \pm 1$ & $17 \pm 1$ \\
\hline Satellite data & $183 \pm 1$ & $14 \pm 1$ & $190 \pm 2$ & $12 \pm 1$ & $182 \pm 1$ & $16 \pm 1$ \\
\hline GEOS-Chem & $183 \pm 1$ & $19 \pm 1$ & $182 \pm 1$ & $12 \pm 1$ & $180 \pm 1$ & $13 \pm 1$ \\
\hline
\end{tabular}

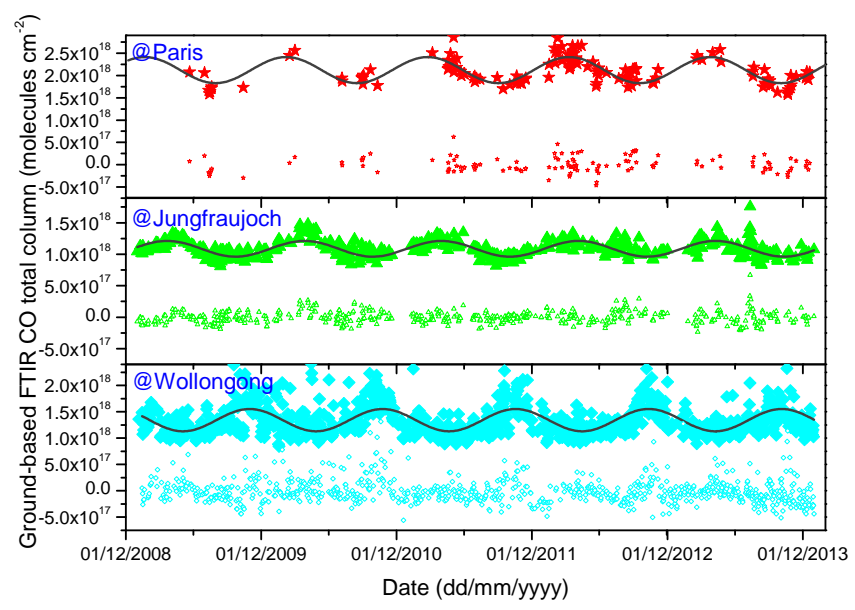

Figure 1. CO total columns retrieved by ground-based FTIR instruments at Paris (top), Jungfraujoch (middle) and Wollongong (bottom). Dark grey lines present CO seasonal variability at each station fitted with sine functions; open symbols represent the residuals from the sine fit.

Solar Observatory at $2.09 \mathrm{~km}$ altitude located in the Northern Hemisphere, by Barret et al. (2003) for Jungfraujoch and by Zhao et al. (2002) for northern Japan. Our observations also agree with a recent 11-year climatology on purely tropospheric CO columns at Northern Hemispheric sites (Zbinden et al., 2013), where observed maxima fall within the period from February to April. In the Southern Hemisphere, we observe an expected shift of 6 months compared to the Northern Hemisphere, with a maximum in October and a minimum in April. The average half-period is about $178 \pm 1$ days. We also note that the relative amplitude of the seasonal variation is slightly higher at Wollongong $(17 \%)$ than at Paris, but it remains close within error bars. Interestingly, the relative amplitude is lowest at Jungfraujoch, where the impact of the local surface emissions is small.

The seasonal variability of $\mathrm{CO}$ is also observed by the IASI-MetOp and MOPITT instruments, cf. Fig. 2 and Table 2. One of the advantages of the satellite measurements is their spatial coverage. In general, the period and amplitude of the seasonal variability obtained from the satellite data agree

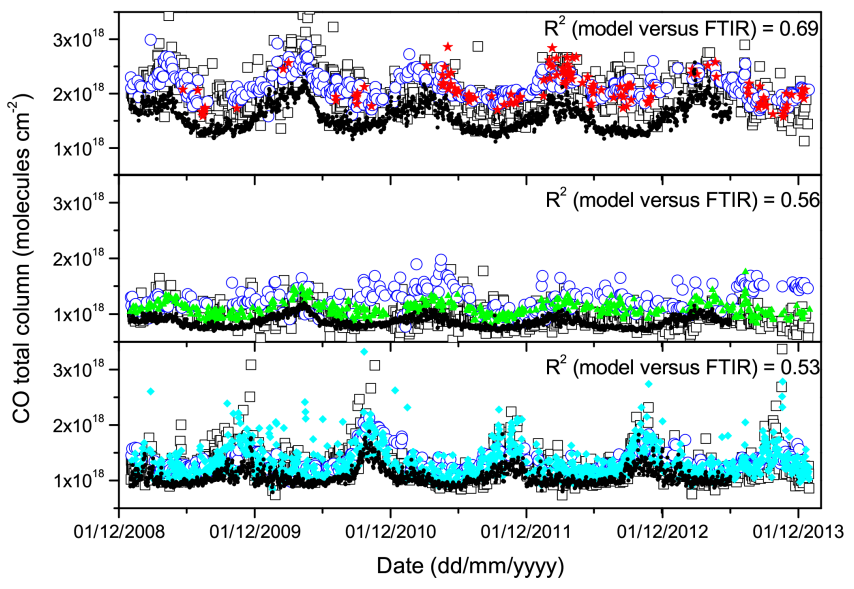

Figure 2. Time series of $\mathrm{CO}$ columns from satellite instruments and ground-based FTIR are given for Paris, Jungfraujoch and Wollongong (from top to bottom). IASI-MetOp and MOPITT columns are displayed as black open squares and blue open circles. Groundbased FTIR CO total columns are shown by red stars, green triangles and cyan diamonds for Paris, Jungfraujoch and Wollongong respectively. GEOS-Chem CO total columns are indicated by black full circles.

with the corresponding values from the ground-based FTIR measurements.

For the Jungfraujoch station, the satellite data need to be recalculated in order to correspond to the column between the ground altitude and the top of the atmosphere (Barret et al., 2003), because the large satellite footprint not only includes the site, but also neighbouring areas of lower altitude. Concerning the IASI-MetOp data, the contributions from levels below the Jungfraujoch altitude have been subtracted from the total columns. For the MOPITT data, we extracted the retrieved CO profile for Jungfraujoch and interpolated the lower pressure levels onto a thinner vertical grid in order to calculate the column between the given ground altitude and the top of the atmosphere. MOPITT measurements are performed for specific ground altitudes, which, however, are not made available. We have assumed a ground altitude of about $1100 \mathrm{~m}$, which is the mean altitude for the Bern canton ${ }^{3}$, to

\footnotetext{
${ }^{3}$ https://lta.cr.usgs.gov/GTOPO30 (Global 30 Arc-Second Elevation)
} 


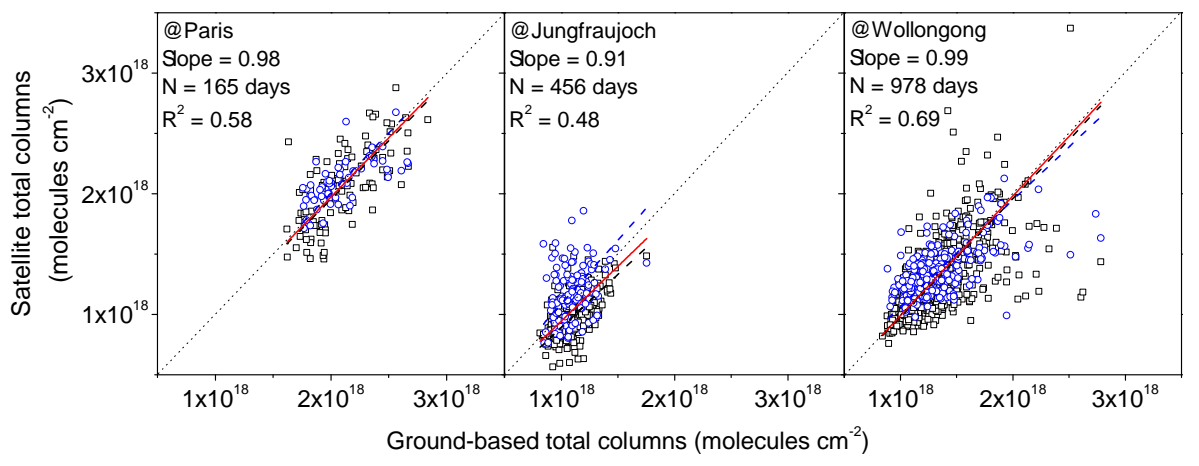

Figure 3. Correlation between satellite (IASI and MOPITT) and ground-based FTIR total columns at the three different sites, IASI data are in black squares and MOPITT data in blue circles. The dark dotted line and the blue dotted line are the robust regression fit results for IASI-MetOp and MOPITT respectively. Slope values are obtained using both data sets (red line).

which Jungfraujoch belongs. Partial columns above $1100 \mathrm{~m}$ were then calculated using the interpolated $\mathrm{CO}$ vertical profiles and daily NCEP meteorological pressure and temperature profiles. Data from the ground-based FTIR instruments and satellites are in good agreement. This is demonstrated in Fig. 3, in which the satellite data are plotted against the ground-based measurements. The agreement is indicated by robust fits yielding slopes of 0.98 for Paris, 0.91 for Jungfraujoch and 0.99 for Wollongong. The robust fit regression is based on a process called iteratively reweighted least squares (Street et al., 1988) and is less sensitive than ordinary least squares to large changes in small parts of the data.

GEOS-Chem model outputs are presented in Fig. 2 for the entire period from the beginning of 2009 to June 2013. The model is in good agreement with ground-based observations ( $R^{2}$ between 0.53 and 0.69), even if the observed total atmospheric $\mathrm{CO}$ abundance is underestimated at all three sites. The relative deviations are commensurate: $-24 \%$ for Paris, $-21 \%$ for Jungfraujoch and $-20 \%$ for Wollongong. In Duncan et al. (2007), the averaged bias between observations and GEOS-Chem model simulations is less than $\pm 10 \%$, but for some sites (Seychelles or Tae-Ahn), the bias can exceed $\pm 20 \%$. Zeng et al. (2015) observed large underestimations from models when compared to the ground-based FTIR stations in the Southern Hemisphere, ranging from -19.2 to $-27.5 \%$, and concluded that differences depend on the emission inventories implemented in the models for the Wollongong site (episodic events are unaccounted for in the emission inventories). The present deviations are also consistent with previous inverse modelling studies (Kopacz et al., 2010; Hooghiemstra et al., 2012) and could originate from an underestimation of the emissions of CO and its VOC precursors in the inventories currently implemented in GEOSChem. Nonetheless, exploring this discrepancy was beyond the scope of this paper, which aims to study the seasonal variability of $\mathrm{CO}$ rather than reproducing observed concentrations. Thus, it has to be underlined that the model shows the same seasonal variability as the measurements: GEOS-Chem simulations reproduce the Northern Hemisphere maximum in March-April and the minimum in September-October, and the model is therefore appropriate for diagnosing the seasonal variability. Both the period and the relative amplitude of the variability are comparable to the measurement results, cf. Table 2. The lower $R^{2}$ between GEOS-Chem and groundbased FTIR for Jungfraujoch and Wollongong compared to Paris are probably due to the more complex orography at these two sites: Jungfraujoch is located in the highest part of the Swiss Alps and the surroundings show very large differences in altitude; Wollongong is sandwiched between the ocean (Tasman Sea) and a mountainous region (Blue Mountains) with a typical altitude of a few hundred metres.

\subsection{In situ measurements of surface $\mathrm{CO}$}

Daily averages of the surface CO concentration during the 2009-2013 period at Paris are plotted in the bottom panel of Fig. 4. Since only very few FTS-Paris data are available for the winter months, January and December, the corresponding monthly means have not been presented in Fig. 4.

The figure shows a clear seasonal variability with a maximum around January-February and a minimum around JulyAugust. The amplitude of the seasonal variation is about $30 \%$, which is larger than the total column variability. This shows a stronger and more direct influence of local CO emissions due to anthropogenic activities, which are expected to be particularly high in a megacity. As mentioned in Sect. 2.1, the retrieval grid (49 levels) provides a much thinner atmospheric layering than the effective vertical resolution indicated by the averaging kernels (Rodgers, 1990). The CO averaging kernels for each altitude of the a priori profile indicate high sensitivity of the FTS-Paris instrument to the PBL. Effectively, the left panel of Fig. 5 shows that the retrieval of $\mathrm{CO}$ essentially provides two independent measurements of tropospheric CO: the first supplies maximal information in the altitude range between 0 and $1000 \mathrm{~m}$, thus well represents the PBL. The comparability between FTIR retrievals and surface in situ observations is thus assured. The sec- 


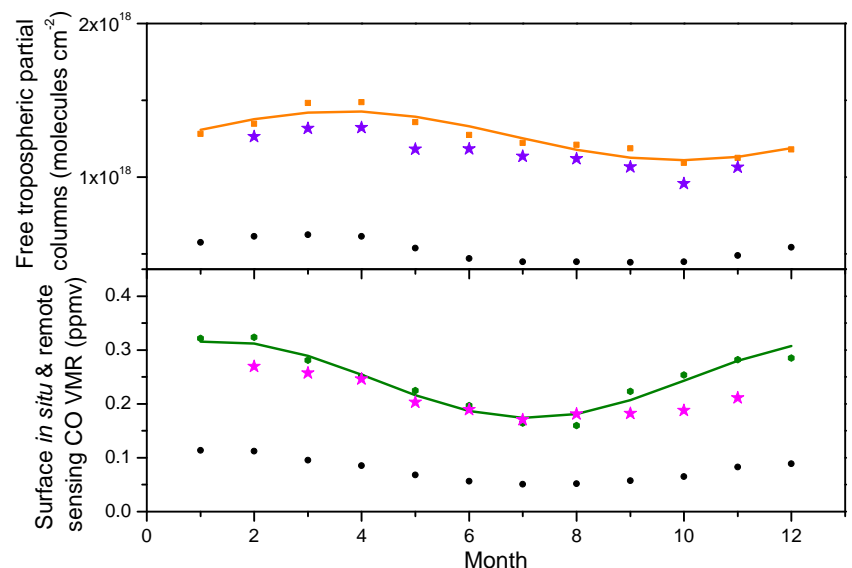

Figure 4. Free tropospheric (top) and surface (bottom) $\mathrm{CO}$ at Paris as monthly averages over 5 years. CO VMR in the PBL comes from the in situ $\mathrm{CO}$ analyser (dark green hexagons) and the FTS-Paris (magenta stars), as well as from the GEOS-Chem model (black circles). Free tropospheric CO columns were calculated between 2 and $12 \mathrm{~km}$ and monthly averaged over the period from 2009 to 2013. Shown are data from IASI-MetOp (orange squares), FTSParis (purple stars) and GEOS-Chem modelling (black circles). A sine function fit is applied to the IASI-MetOp (orange line) and in situ CO data (dark green line).

ond one is representative of the upper troposphere, with a maximum around $8-9 \mathrm{~km}$. The FTS-Paris data in the bottom panel of Fig. 4 represent the averaged CO VMR obtained for the altitude range between the ground $(60 \mathrm{~m}$ a.s.l.) and the $1000 \mathrm{~m}$ level. These remote sensing measurements are consistent with the in situ data, even if they are much less affected by local pollution peaks. By comparing Figs. 1 and 4, we notice that the seasonal variability of the total column is shifted by about 2 months compared to the variability at the surface. The free tropospheric columns of $\mathrm{CO}$ have been calculated as partial columns between 2 and about $12 \mathrm{~km}$ over Paris for both IASI-MetOp and FTS-Paris. The right panel of Fig. 5 shows the July 2010 monthly averaged AVKs of IASI-MetOp. These AVKs show a relatively low surface sensitivity which is more emphasised during winter (we have also checked the January 2010 monthly averaged AVKs not shown here). We thus only exploit the partial columns corresponding to the free troposphere. The seasonal variability in the free troposphere obtained by the three different kinds of data is also shifted by 2 months compared to the surface seasonal variation. In addition to local surface sources, column abundances are influenced by the transport of downwind emission sources. The surface seasonal variability is directly influenced by the local emission due to human activities: fossil fuel combustion, domestic heating and industrial activities. In contrast, the total column seasonal variability is additionally influenced by emissions from distant sources that get transported into the upper levels of the atmosphere. The surface CO maximum in January-February corresponds to

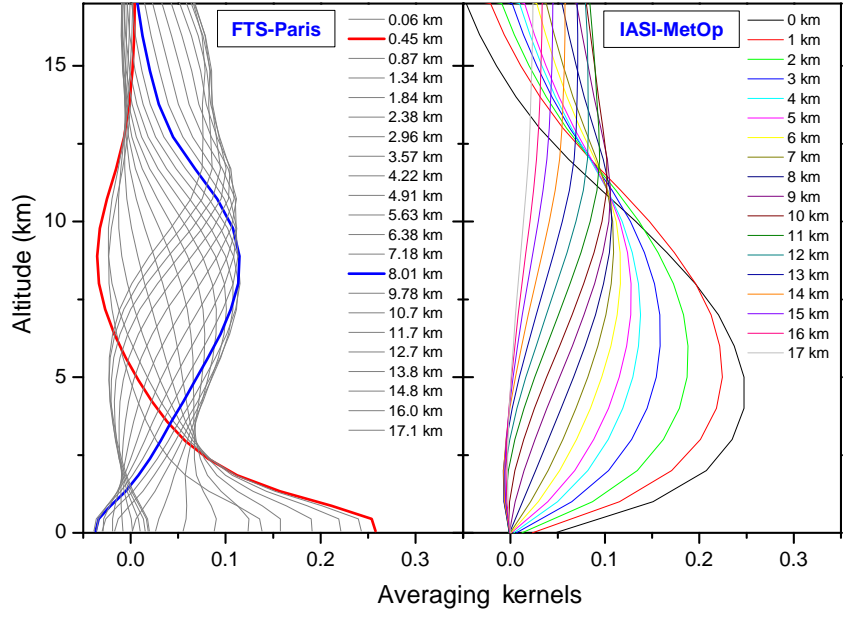

Figure 5. $\mathrm{CO}$ averaging kernels for each altitude of the a priori profile (from 0 to $17 \mathrm{~km}$ ) for FTS-Paris (left panel) and IASI-MetOp (right panel).

the winter season, when domestic heating is strong and the $\mathrm{PBL}$ height is reduced. Additionally, oxidation by $\mathrm{OH}$ is lowest due to weak actinic flux. The minimum in July-August, when the PBL height is highest, not only corresponds to an increased oxidisation of $\mathrm{CO}$ by $\mathrm{OH}$, the abundance of which is influenced by solar ultraviolet radiation (Bousquet et al., 2005; Rohrer and Berresheim, 2006; Duncan et al., 2007), but also to the summer vacation season during which the inhabitants of Paris usually leave the city (by more than $50 \%$, http://www.insee.fr), leading to a drastic decrease of vehicle traffic. In order to check the consistency of the GEOS-Chem model, we have plotted the GEOS-Chem surface VMR in the bottom panel of Fig. 4. The model confirms the time shift between surface and total column seasonal variability, with a surface maximum at the end of January-February and a minimum at the end of July-August. We once again notice an underestimation of the surface CO VMR by the GEOSChem model. The discrepancy of about $-37 \%$ is larger than the difference of $-24 \%$ between GEOS-Chem and groundbased total columns and can probably be attributed to strong local emissions, which are not in the current emission inventories implemented in GEOS-Chem.

There is also a temporal shift in seasonal variations between the surface and the high altitudes in Switzerland, as indicated by the difference between urban and mountain sites. This is shown in Fig. 6, which compares the four urban NABEL sites with an average altitude of $438.25 \mathrm{~m}$ a.s.l. to the in situ surface CO obtained on top of Jungfraujoch at an altitude of $3578 \mathrm{~m}$ a.s.l. The low-altitude sites show a similar seasonal variability to the surface $\mathrm{CO}$ at Paris, with a maximum around January and a minimum around July. Zellweger et al. (2009) point out that the in situ observations at Swiss urban stations reliably represent the mixture of traffic and industrial emissions. 


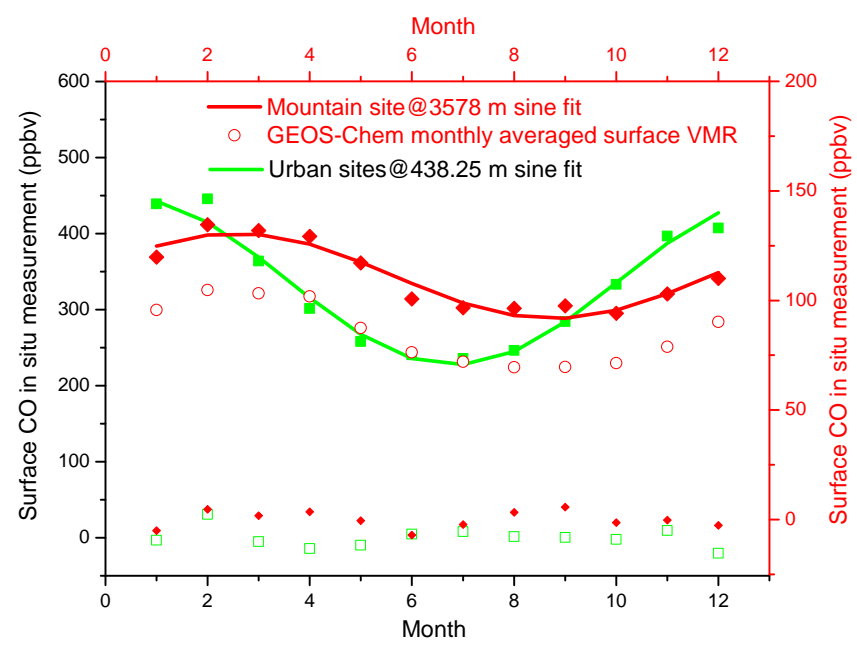

Figure 6. Monthly averaged $\mathrm{CO}$ in situ measurements at the surface in Switzerland using Swiss NABEL data from 2009 to 2013 (green squares are the means of the four urban sites and red diamonds are for Jungfraujoch). The sine function fit is applied to the 5-year monthly means of urban (green line) and mountain (red line) sites. The two lowermost data sets show the residuals of the fit (green open squares for urban sites and red small diamonds for Jungfraujoch). Monthly averaged CO surface VMR from GEOSChem located at Jungfraujoch is shown in red open circles.

In contrast, in situ surface $\mathrm{CO}$ at Jungfraujoch shows the same seasonal variability as the whole atmosphere (characterised by the total column seasonality) and is shifted by 2 months with respect to the urban sites. This is in agreement with the GEOS-Chem model at Jungfraujoch. Unlike the model at Paris, where the underestimation is much stronger, GEOS-Chem underestimates the CO surface VMR by about $23 \%$ at Jungfraujoch, which is similar to the $21 \%$ difference obtained for the total columns. This is consistent with the much lower influence from low-altitude emissions and the PBL.

Figure 7 shows the monthly averaged surface $\mathrm{CO}$ in situ measurements performed at Wollongong between June 2012 and May 2013. We observe a surface seasonality with a maximum around October and a minimum in February-March. The maximum corresponds to elevated biomass burning levels during the Southern Hemisphere spring (Edwards et al., 2006). Unlike the two Northern Hemisphere sites, there is no significant time shift between the $\mathrm{CO}$ seasonal variabilities at the Wollongong surface level and at higher altitudes. This suggests that the Wollongong surface atmosphere is more representative of the free troposphere. The GEOSChem monthly averaged surface VMR shows a maximum during the austral spring and a lower level after the end of the austral summer until the austral winter. A striking increase after March 2013 is observed by the surface in situ measurements, but not by the GEOS-Chem model. This might be due to nearby local emission sources which are probably not

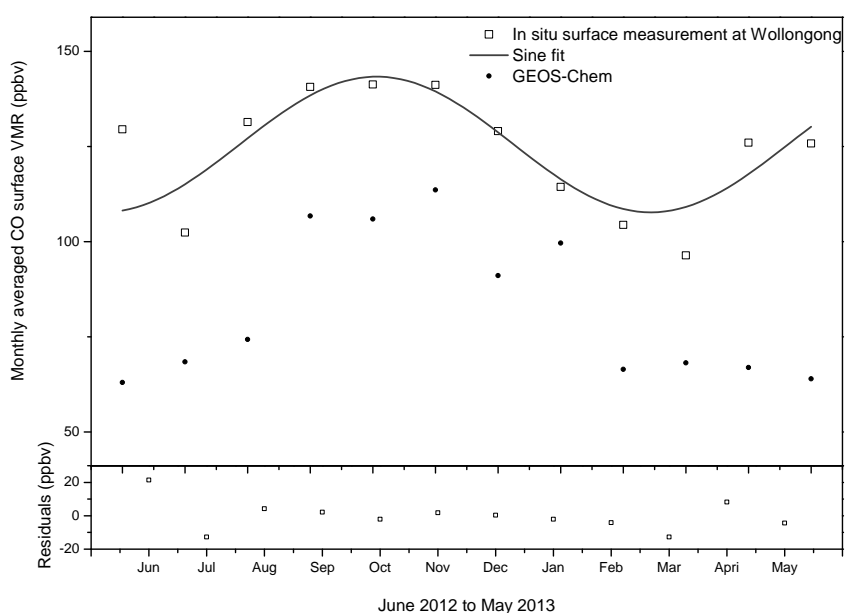

Figure 7. Monthly averaged CO surface VMR at Wollongong from in situ measurements (black open squares) and the GEOS-Chem model (black full circles) from June 2012 to May 2013. The sine function fit residuals are shown in the bottom panel.

referenced in the inventories implemented in GEOS-Chem. A longer time series of these measurements will be helpful to better understand this observation. The background seasonality of $\mathrm{CO}$ is mainly driven by biomass burning sources modulated by the OH sink (Buchholz et al., 2016b). Similarly to Paris, the surface CO discrepancy between model and measurement of $-33 \%$ is slightly increased compared to the value of $-20 \%$ for the total columns.

\subsection{Emission sources impacting the seasonality of $\mathrm{CO}$ columns}

In order to study the influence of the different categories of $\mathrm{CO}$ and NMVOC emissions on the CO total column and its seasonality at the three sites, we perform three GEOS-Chem sensitivity simulations. These relied on the same set-up as for the standard run (standard chemistry, horizontal resolution, time period, etc.), but in each of these simulations we turned off either the biogenic, the anthropogenic (incorporating the biofuel emissions) or the biomass burning emission sources implemented in the model. These categories include direct emissions of $\mathrm{CO}$ (for both anthropogenic and biomass burning sources) and its NMVOC precursor emissions, as well as direct emissions of nitric oxide (NO). In these three sensitivity runs - hereafter referred to as the nonbiogenic, non-anthropogenic and non-biomass burning simulations $-\mathrm{CH}_{4}$ concentrations are based on measurements from NOAA. The results of these GEOS-Chem sensitivity simulations are compared to the standard run (results shown in Fig. 2). All four runs cover the mid-2005 to mid-2013 time period, hence starting a few years before our period under investigation. This allows us to establish a stable situation for the period 2008 (most of the long-lived precursors of $\mathrm{CO}$ are removed from the atmosphere between mid-2005 and 2008). 
Figure 8 shows the $\mathrm{CO}$ total columns simulated by the different runs of GEOS-Chem for the three sites. The results for Paris and Jungfraujoch are quite similar. At these two sites, the seasonal variability of the CO loadings is mainly driven by anthropogenic emissions. Indeed, by shutting off the anthropogenic emissions of CO and its NMVOC precursors, the amplitude of the $\mathrm{CO}$ seasonal variation and periodicity are radically reduced. This is in agreement with previous model studies. Duncan et al. (2007) show that fossil fuel emissions are the main contribution to the $\mathrm{CO}$ burden in the northern extratropics. The high-altitude Jungfraujoch site is strongly impacted by long-range transport of $\mathrm{CO}$. At least one-third of it is of non-European origin (Duncan et al., 2007; Zellweger et al., 2009). In comparison, shutting off either biomass burning or biogenic emissions only weakly affects the seasonal variation and maximum peaks. Compared to the standard run, $\mathrm{CO}$ columns are marginally lower due to some missing emissions. At Wollongong, the seasonal variability is mainly influenced by the biomass burning emissions: the highest peaks (e.g. at the end of 2009) disappear when the biomass burning component is removed from the simulation. The biogenic emissions provide the largest background contribution. Zeng et al. (2015) have observed that the impact of biogenic emissions on CO is larger in the Southern Hemisphere than in the Northern Hemisphere. Unlike at Paris and Jungfraujoch, the influence of anthropogenic emissions is negligible in the Wollongong simulation. We also note that the GEOS-Chem sensitivity runs provide the same results for the CO surface VMR, as for the CO total columns at the three studied sites.

\section{Conclusions}

This paper investigates the seasonal variability of $\mathrm{CO}$ total columns at three NDACC/TCCON sites: Paris and Jungfraujoch in the Northern Hemisphere and Wollongong in the Southern Hemisphere. In the Northern Hemisphere, the variability of $\mathrm{CO}$ above the PBL has a seasonal maximum in March-April and a minimum in September-October. In the Southern Hemisphere, this seasonal variation is shifted by 6 months. We have compared the ground-based FTIR data to satellite measurements from IASI-MetOp and MOPITT and to GEOS-Chem model standard outputs, which confirm the observed $\mathrm{CO}$ seasonal variability. However with currently implemented inventories, an underestimation of about $20 \%$ by the GEOS-Chem model is observed, which is consistent with previous forward and inverse modelling studies. Interestingly, a time lag of about 2 months between upper altitude and surface $\mathrm{CO}$ has been found in the measurements and GEOS-Chem in both Paris and Jungfraujoch. This time lag is likely due to the different emission patterns. Custom simulations with emission sources being individually turned on and off show that the CO seasonality at Paris and Jungfraujoch is mainly controlled by anthropogenic emissions. In Wol-

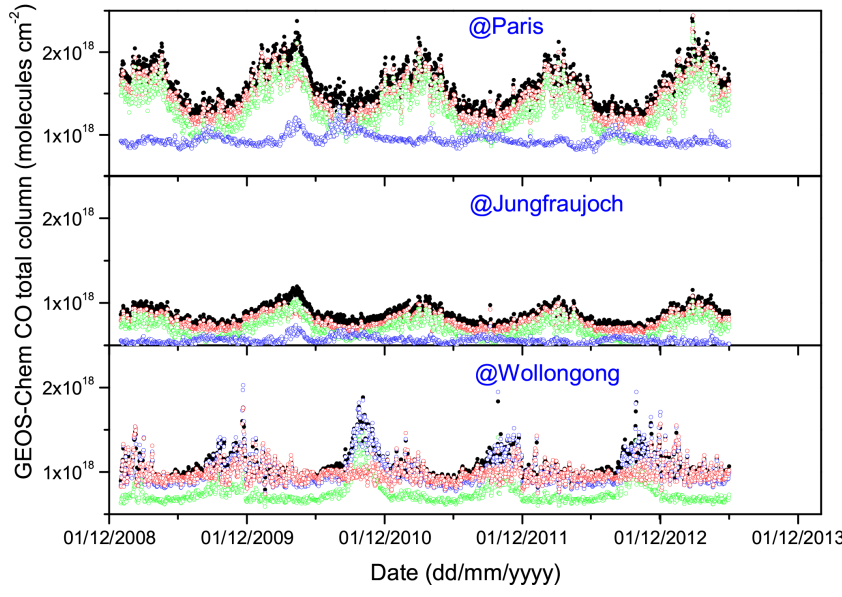

Figure 8. GEOS-Chem time series of $\mathrm{CO}$ total columns for Paris (top), Jungfraujoch (middle) and Wollongong (bottom). Different colours indicate standard run (black), run without biomass burning (red), run without biogenic emissions (green) and run without anthropogenic emissions (blue).

longong, where low local anthropogenic emissions prevail and the impact of biomass burning and biogenic emissions is large, such a time shift is neither observed nor modelled. We have thus observed a temporal shift in the seasonal patterns at the surface and in the higher atmospheric layers for the sites that are strongly affected by local anthropogenic emissions. The observation of the time lag is likely due to zonal mixing occurring on a shorter (1-2 weeks) timescale than complete vertical tropospheric mixing (1-2 months). In the future, it will be interesting to study the link between local and nonlocal emission sources and the magnitude of the time shift between surface and total column CO by extending the present study to more sites and improving the analysis of the temporal signals. The presence of global ground-based FTIR networks provides a unique opportunity to obtain these data on a global scale, as the instruments are capable of sampling the surface and the total column data at the same time. The time lag data might also provide an additional benchmark parameter for chemical transport models and emission inventories, taking into account that the modelling of vertical $\mathrm{CO}$ gradients in the remote Southern Hemisphere already provides a challenge for chemical transport modelling (Fisher et al., 2015).

\section{Data availability}

Data used in the paper are either publicly available or made accessible in Supplement. The CO total column data from NDACC stations at Jungfraujoch and Wollongong are publicly accessible (Mahieu, 2014; Griffith, 2015). Corresponding data from the MOPITT and IASI satellites are also freely available (Deeter et al., 2014; Clerbaux, 2014). The Swiss in situ data have been published by Ballaman (2014) and 
Wollongong surface measurements are publicly available via PANGAEA (Buchholz et al., 2016a). Paris station data are provided via the Supplement to this article.

\section{The Supplement related to this article is available online at doi:10.5194/acp-16-10911-2016-supplement.}

Acknowledgements. We are grateful to Université Pierre et Marie Curie and Région Île-de-France for their financial contributions as well as to Institut Pierre-Simon Laplace for support and facilities. We thank the National Center for Atmospheric Research MOPITT science team and NASA for producing and archiving the MOPITT CO product. Thanks are also due to the Swiss National Air Pollution Monitoring Network (NABEL) for delivering ground data around Switzerland. The University of Liège contribution to the present work has primarily been supported by the F.R.S.-FNRS, the Fédération Wallonie-Bruxelles and MeteoSwiss (GAW-CH programme). We thank the International Foundation High Altitude Research Stations Jungfraujoch and Gornergrat (HFSJG, Bern). We are grateful to all colleagues who contributed to the acquisition of the FTIR data. The Australian Research Council has provided financial support over the years for the NDACC site at Wollongong, most recently as part of project DP110101948. We also acknowledge the important contribution to the measurement programme at Wollongong made by researchers other than those listed as coauthors here, including Voltaire Velazco and Nicholas Deutscher. IASI has been developed and built under the responsibility of the French space agency CNES. It is flown on board the MetOp satellite as part of the EUMETSAT Polar System (EPS). The IASI L1 data are received through the Eumetcast near real time data distribution service. IASI data are stored in the French atmospheric database ETHER. The National Center for Atmospheric Research (NCAR) is sponsored by the National Science Foundation.

Disclaimer. Any opinions, findings and conclusions or recommendations expressed in the publication are those of the author(s) and do not necessarily reflect the views of the National Science Foundation.

Edited by: P. O. Wennberg

Reviewed by: two anonymous referees

\section{References}

August, T., Klaes, D., Schlüssel, P., Hultberg, T., Crapeau, M., Arriaga, A., O'Carroll, A., Coppens, D., Munro, R., and Calbet, X.: IASI on MetOp-A: Operational Level 2 retrievals after five years in orbit, J. Quant. Spectrosc. Ra., 113, 1340-1371, doi:10.1016/j.jqsrt.2012.02.028, 2012.

Bakwin, P. S., Tans, P. P., and Novelli, P. C.: Carbon monoxide budget in the northern hemisphere, Geophys. Res. Lett., 21, 433436, 1994.

Ballaman, R.: Swiss surface monthly averaged CO data, available at: http://www.bafu.admin.ch/publikationen/00016 (last access: January 2015), 2014.
Barret, B., De Mazière, M., and Mahieu, E.: Ground-based FTIR measurements of $\mathrm{CO}$ from the Jungfraujoch: characterisation and comparison with in situ surface and MOPITT data, Atmos. Chem. Phys., 3, 2217-2223, doi:10.5194/acp-3-2217-2003, 2003.

Bekki, S., Law, K. S., and Pyle, J. A.: Effect of ozone depletion on atmospheric $\mathrm{CH}_{4}$ and $\mathrm{CO}$ concentrations, Nature, 371, 595-597, doi:10.1038/371595a0, 1994.

Benedictow, A., Berge, H., Fagerli, H., Gauss, M., Jonson, J. E., Nyíri, A., Simpson, D., Tsyro, S., Valdebenito, A., Shamsudheen, V. S., Wind, P., Aas, W., Hjellbrekke, A.-G., Mareckova, K., Wankmüller, R., Iversen, T., Kirkevøag, A., Seland, Ø., Haugen, J. E., and Mills, G.: Transboundary acidification, eutrophication and ground level ozone in Europe in 2008, Tech. rep., The Norwegian Meteorological Institute, Oslo, Norway, 2010.

Bey, I., Jacob, D. J., Yantosca, R. M., Logan, J. A., Field, B. D., Fiore, A. M., Li, Q., Liu, H. Y., Mickley, L. J., and Schultz, M. G.: Global modeling of tropospheric chemistry with assimilated meteorology: model description and evaluation, J. Geophys. Res.-Atmos., 106, 23073-23095, doi:10.1029/2001JD000807, 2001.

Blumstein, D., Chalon, G., Carlier, T., Buil, C., Hebert, P., Maciaszek, T., Ponce, G., Phulpin, T., Tournier, B., Simeoni, D., Astruc, P., Clauss, A., Kayal, G., and Jegou, R.: IASI instrument: technical overview and measured performances, in: Proc. SPIE 5543, Infrared Spaceborne Remote Sensing XII, doi:10.1117/12.560907, 2004.

Bousquet, P., Hauglustaine, D. A., Peylin, P., Carouge, C., and Ciais, P.: Two decades of $\mathrm{OH}$ variability as inferred by an inversion of atmospheric transport and chemistry of methyl chloroform, Atmos. Chem. Phys., 5, 2635-2656, doi:10.5194/acp-52635-2005, 2005.

Brunke, E.-G., Scheel, H., and Seiler, W.: Trends of tropospheric $\mathrm{CO}, \mathrm{N}_{2} \mathrm{O}$ and $\mathrm{CH}_{4}$ as observed at cape point, South Africa, Atmos. Environ., 24, 585-595, doi:10.1016/0960-1686(90)90013D, 1990.

Buchholz, R. R., Paton-Walsh, C., Griffith, D. W. T., Kubistin, D., Caldow, C., Fisher, J. A., Deutscher, N. M., Kettlewell, G., Riggenbach, M., Macatangay, R., Krummel, P. B., and Langenfelds, R. L.: Wollongong surface CO data, PANGAEA, doi:10.1594/PANGAEA.848263, 2016a.

Buchholz, R. R., Paton-Walsh, C., Griffith, D. W. T., Kubistin, D., Caldow, C., Fisher, J. A., Deutscher, N. M., Kettlewell, G., Riggenbach, M., Macatangay, R., Krummel, P. B., and Langenfelds, R. L.: Source and meteorological influences on air quality $\left(\mathrm{CO}, \mathrm{CH}_{4} \& \mathrm{CO}_{2}\right)$ at a Southern Hemisphere urban site, Atmos. Environ., 126, 274-289, doi:10.1016/j.atmosenv.2015.11.041, 2016b.

Clerbaux, C.: IASI satellite CO data, available at: http://www. pole-ether.fr (last access: January 2015), 2014.

Clerbaux, C., George, M., Turquety, S., Walker, K. A., Barret, B., Bernath, P., Boone, C., Borsdorff, T., Cammas, J. P., Catoire, V., Coffey, M., Coheur, P.-F., Deeter, M., De Mazière, M., Drummond, J., Duchatelet, P., Dupuy, E., de Zafra, R., Eddounia, F., Edwards, D. P., Emmons, L., Funke, B., Gille, J., Griffith, D. W. T., Hannigan, J., Hase, F., Höpfner, M., Jones, N., Kagawa, A., Kasai, Y., Kramer, I., Le Flochmoën, E., Livesey, N. J., López-Puertas, M., Luo, M., Mahieu, E., Murtagh, D., Nédélec, P., Pazmino, A., Pumphrey, H., Ricaud, P., Rinsland, C. 
P., Robert, C., Schneider, M., Senten, C., Stiller, G., Strandberg, A., Strong, K., Sussmann, R., Thouret, V., Urban, J., and Wiacek, A.: CO measurements from the ACE-FTS satellite instrument: data analysis and validation using ground-based, airborne and spaceborne observations, Atmos. Chem. Phys., 8, 2569-2594, doi:10.5194/acp-8-2569-2008, 2008.

Clerbaux, C., Boynard, A., Clarisse, L., George, M., Hadji-Lazaro, J., Herbin, H., Hurtmans, D., Pommier, M., Razavi, A., Turquety, S., Wespes, C., and Coheur, P.-F.: Monitoring of atmospheric composition using the thermal infrared IASI/MetOp sounder, Atmos. Chem. Phys., 9, 6041-6054, doi:10.5194/acp-9-6041-2009, 2009.

Deeter, M., Emmons, L., Francis, G., Edwards, D., Gille, J., Warner, J., Khattatov, B., Ziskin, D., Lamarque, J.-F., Ho, S.-P., Yudin, V., Attié, J.-L., Packman, D., Chen, J., Mao, D., Drummond, J., Novelli, P., and Sachse, G.: Evaluation of operational radiances for the Measurements of Pollution in the Troposphere (MOPITT) instrument CO thermal band channels, J. Geophys. Res., 109, D03308, doi:10.1029/2003JD003970, 2004.

Deeter, M. N., Martínez-Alonso, S., Edwards, D. P., Emmons, L. K., Gille, J. C., Worden, H. M., Sweeney, C., Pittman, J. V., Daube, B. C., and Wofsy, S. C.: MOPITT satellite CO data, available at: https://eosweb.larc.nasa.gov/datapool (last access: January 2015), 2014.

Dils, B., Cui, J., Henne, S., Mahieu, E., Steinbacher, M., and De Mazière, M.: 1997-2007 CO trend at the high Alpine site Jungfraujoch: a comparison between NDIR surface in situ and FTIR remote sensing observations, Atmos. Chem. Phys., 11, 6735-6748, doi:10.5194/acp-11-6735-2011, 2011.

Drummond, J. and Mand, G.: The Measurements of Pollution in the Troposphere (MOPITT) Instrument: Overall Performance and Calibration Requirements, J. Atmos. Ocean. Tech., 13, 314-320, 1996.

Duchatelet, P., Demoulin, P., Hase, F., Ruhnke, R., Feng, W., Chipperfield, M. P., Bernath, P. F., Boone, C. D., Walker, K. A., and Mahieu, E.: Hydrogen fluoride (HF) total and partial column time series above the Jungfraujoch from long-term FTIR measurements: impact of the line-shape model, error budget, seasonal cycle and comparison with satellite and model data, J. Geophys. Res., 115, D22306, doi:10.1029/2010JD014677, 2010.

Duncan, B. N., Logan, J. A., Bey, I., Megretskaia, I. A., Yantosca, R. M., Novelli, P. C. Jones, N. B., and Rinsland, C. P.: Global budget of CO, 1988-1997: Source estimates and validation with a global model, J. Geophys. Res.-Atmos., 112, D22301, doi:10.1029/2007JD008459, 2007.

Edwards, D. P., Pétron, G., Novelli, P. C., Emmons, L. K., Gille, J. C., and Drummond, J. R.: Southern Hemisphere carbon monoxide interannual variability observed by Terra/Measurement of Pollution in the Troposphere (MOPITT), J. Geophys. Res., 111, D16303, doi:10.1029/2006JD007079, 2006.

Esposito, F., Grieco, G., Masiello, G., Pavese, G., Restieri, R., Serio, C., and Cuomo, V.: Intercomparison of line-parameter spectroscopic databases using downwelling spectral radiance, Q. J. Roy. Meteor. Soc., 133, 191-202, doi:10.1002/qj.131, 2007.

Fisher, J. A., Wilson, S. R., Zeng, G., Williams, J. E., Emmons, L. K., Langenfelds, R. L., Krummel, P. B., and Steele, L. P.: Seasonal changes in the tropospheric carbon monoxide profile over the remote Southern Hemisphere evaluated using multi-model simulations and aircraft observations, Atmos. Chem. Phys., 15, 3217-3239, doi:10.5194/acp-15-3217-2015, 2015.

George, M., Clerbaux, C., Hurtmans, D., Turquety, S., Coheur, P.F., Pommier, M., Hadji-Lazaro, J., Edwards, D. P., Worden, H., Luo, M., Rinsland, C., and McMillan, W.: Carbon monoxide distributions from the IASI/METOP mission: evaluation with other space-borne remote sensors, Atmos. Chem. Phys., 9, 8317-8330, doi:10.5194/acp-9-8317-2009, 2009.

Griffith, D.: NDACC CO data for Wollongong, available at: ftp://ftp.cpc.ncep.noaa.gov/ndacc/station/wollong/, last access: July 2015.

Griffith, D. W. T.: Synthetic Calibration and Quantitative Analysis of Gas-Phase infrared Spectra, Appl. Spectrosc., 50, 59-70, 1996.

Griffith, D. W. T., Deutscher, N. M., Caldow, C., Kettlewell, G., Riggenbach, M., and Hammer, S.: A Fourier transform infrared trace gas and isotope analyser for atmospheric applications, Atmos. Meas. Tech., 5, 2481-2498, doi:10.5194/amt-5-2481-2012, 2012.

Guenther, A., Karl, T., Harley, P., Wiedinmyer, C., Palmer, P. I., and Geron, C.: Estimates of global terrestrial isoprene emissions using MEGAN (Model of Emissions of Gases and Aerosols from Nature), Atmos. Chem. Phys., 6, 3181-3210, doi:10.5194/acp-63181-2006, 2006.

Hase, F., Hannigan, J. W., Coey, M. T., Goldman, A., Höpfner, M., Jones, N. B., Rinsland, C. P., and Wood, S. W.: Intercomparison of retrieval codes used for the analysis of high-resolution: ground-based FTIR measurements, J. Quant. Spectrosc. Ra., 87, 25-52, 2004.

Hase, F., Demoulin, P., Sauval, A. J., Toon, G. C., Bernath, P. F., Goldman, A., Hannigan, J. W., and Rinsland, C. P.: An empirical line-by-line model for the infrared solar transmittance spectrum from 700 to $5000 \mathrm{~cm}^{-1}$, J. Quant. Spectrosc. Ra., 102, 450-463, doi:10.1016/j.jqsrt.2006.02.026, 2006.

Holloway, T., Levy, H., and Kasibhatla, P.: Global distribution of carbon monoxide, J. Geophys. Res.-Atmos., 105, 12123-12147, doi:10.1029/1999JD901173, 2000.

Hooghiemstra, P. B., Krol, M. C., Bergamaschi, P., de Laat, A. T. J., van der Werf, G. R., Novelli, P. C., Deeter, M. N., Aben, I., and Röckmann, T.: Comparing optimized $\mathrm{CO}$ emission estimates using MOPITT or NOAA surface network observations, J Geophys. Res.-Atmos., 117, D06309, doi:10.1029/2011JD017043, 2012.

Hurtmans, D., Coheur, P.-F., Wespes, C., Clarisse, L., Scharf, O., Clerbaux, C., Hadji-Lazaro, J., George, M., and Turquety, S.: FORLI radiative transfer and retrieval code for IASI, J. Quant. Spectrosc. Ra., 113, 1391-1408, doi:10.1016/j.jqsrt.2012.02.036, 2006.

Khalil, M. A. K. and Rasmussen, R. A.: Carbon monoxide in the Earth's atmosphere: indications of a global increase, Nature, 332, 242-245, doi:10.1038/332242a0, 1988.

Khalil, M. A. K. and Rasmussen, R. A.: Global decrease in atmospheric carbon monoxide concentration, Nature, 370, 639-641, doi:10.1038/370639a0, 1994.

Kopacz, M., Jacob, D. J., Fisher, J. A., Logan, J. A., Zhang, L., Megretskaia, I. A., Yantosca, R. M., Singh, K., Henze, D. K., Burrows, J. P., Buchwitz, M., Khlystova, I., McMillan, W. W., Gille, J. C., Edwards, D. P., Eldering, A., Thouret, V., and Nedelec, P.: Global estimates of CO sources with high resolu- 
tion by adjoint inversion of multiple satellite datasets (MOPITT, AIRS, SCIAMACHY, TES), Atmos. Chem. Phys., 10, 855-876, doi:10.5194/acp-10-855-2010, 2010.

Logan, J. A., Prather, M. J., Wofsy, F. C., and McElroy, M. B.: Tropospheric Chemistry: A Global Perspective, J. Geophys. Res., 86, 7210-7254, 1981.

Mahieu, E.: NDACC CO data for Jungfraujoch, available at: ftp: //ftp.cpc.ncep.noaa.gov/ndacc/station/jungfrau/ (last access: January 2015), 2014.

Mahieu, E., Zander, R., Delbouille, L., Demoulin, P., Roland, G., and Servais, C.: Observed Trends in Total Vertical Column Abundances of Atmospheric Gases from IR Solar Spectra Recorded at the Jungfraujoch, J. Atmos. Chem., 28, 227-243, doi:10.1023/A:1005854926740, 1997.

Mao, J., Jacob, D. J., Evans, M. J., Olson, J. R., Ren, X., Brune, W. H., Clair, J. M. St., Crounse, J. D., Spencer, K. M., Beaver, M. R., Wennberg, P. O., Cubison, M. J., Jimenez, J. L., Fried, A., Weibring, P., Walega, J. G., Hall, S. R., Weinheimer, A. J., Cohen, R. C., Chen, G., Crawford, J. H., McNaughton, C., Clarke, A. D., Jaeglé, L., Fisher, J. A., Yantosca, R. M., Le Sager, P., and Carouge, C.: Chemistry of hydrogen oxide radicals $\left(\mathrm{HO}_{x}\right)$ in the Arctic troposphere in spring, Atmos. Chem. Phys., 10, 58235838, doi:10.5194/acp-10-5823-2010, 2010.

Novelli, P. C., Masarie, K. A., Tans, P. P., and Lang, P. M.: Recent Changes in Atmospheric Carbon Monoxide, Science, 263, 15871590, doi:10.1126/science.263.5153.1587, 1994.

Novelli, P. C., Masarie, K. A., and Lang, P. M.: Distributions and recent changes of carbon monoxide in the lower troposphere, J. Geophys. Res.-Atmos., 103, 19015-19033, doi:10.1029/98JD01366, 1998.

Novelli, P. C., Masarie, K. A., Lang, P. M., Hall, B. D., Myers, R. C., and Elkins, J. W.: Reanalysis of tropospheric CO trends: Effects of the 1997-1998 wildfires, J. Geophys. Res.-Atmos., 108, 4464, doi:10.1029/2002JD003031, 2003.

Olivier, J. G. J. and Berdowski, J. J. M.: Global emissions sources and sinks, in: The Climate System, edited by: Berdowski, J., Guicherit, R., and Heij, B., A. A. Balkema Publishers/Swets \& Zeitlinger Publishers, Lisse, the Netherlands, 33-78, 2001.

Park, R. J., Jacob, D. J., Field, B. D., Yantosca, R. M., and Chin, M.: Natural and transboundary pollution influences on sulfate-nitrate-ammonium aerosols in the United States: implications for policy, J. Geophys. Res., 109, D15204, doi:10.1029/2003JD004473, 2004.

Pougatchev, N. S. and Rinsland, C. P.: Spectroscopic study of the seasonal variation of carbon monoxide vertical distribution above Kitt Peak, J. Geophys. Res, 100, 1409-1416, 1995.

Rinsland, C. P., Jones, N. B., Connor, B. J., Logan, J. A., Pougatchev, N. S., Goldman, A., Murcray, F. J., Stephen, T. M., Pine, A. S., Zander, R., Mahieu, E., and Demoulin, P.: Northern and southern hemisphere ground-based infrared spectroscopic measurements of tropospheric carbon monoxide and ethane, J. Geophys. Res., 103, 28197, doi:10.1029/98JD02515, 1998.

Rinsland, C. P., Goldman, A., Murcray, F. J., Stephen, T. M., Pougatchev, N. S., Fishman, J., David, S. J., Blatherwick, R. D., Novelli, P. C., Jones, N. B., and Connor, B. J.: Infrared solar spectroscopic measurements of free tropospheric $\mathrm{CO}, \mathrm{C}_{2} \mathrm{H}_{6}$, and $\mathrm{HCN}$ above Mauna Loa, Hawaii: Seasonal variations and evidence for enhanced emissions from the Southeast Asian tropi- cal fires of 1997-1998, J. Geophys. Res.-Atmos., 104, 1866718680, doi:10.1029/1999JD900366, 1999.

Rinsland, C. P., Mahieu, E., Zander, R., Demoulin, P., Forrer, J., and Buchmann, B.: Free tropospheric $\mathrm{CO}, \mathrm{C}_{2} \mathrm{H}_{6}$, and $\mathrm{HCN}$ above central Europe: Recent measurements from the Jungfraujoch station including the detection of elevated columns during 1998, J. Geophys. Res., 105, 24235-24249, 2000.

Rinsland, C. P., Meier, A., Griffith, D. W. T., and Chiou, L. S.: Ground-based measurements of tropospheric $\mathrm{CO}$, $\mathrm{C}_{2} \mathrm{H}_{6}$, and $\mathrm{HCN}$ from Australia at $34^{\circ} \mathrm{S}$ latitude during 1997-1998, J. Geophys. Res.-Atmos., 106, 20913-20924, doi:10.1029/2000JD000318, 2001.

Rinsland, C. P., Goldman, A., Hanniganc, J. W., Wood, S. W., Chiou, L. S., and Mahieu, E.: Long-term trends of tropospheric carbon monoxide and hydrogen cyanide from analysis of high resolution infrared solar spectra, J. Quant. Spectrosc. Ra., 104, 40-51, 2007.

Rodgers, C. D.: Characterization and error analysis of profiles retrieved from remote sounding measurements, J. Geophys. Res., 95, 5587-5595, doi:10.1029/JD095iD05p05587, 1990.

Rodgers, C. D. and Connor, B. J.: Intercomparison of remote sounding instruments, J. Geophys. Res., 108, 4116-4129, doi:10.1029/2002JD002299, 2003.

Rohrer, F. and Berresheim, H.: Strong correlation between levels of tropospheric hydroxyl radicals and solar ultraviolet radiation, Nature, 442, 184-187, doi:10.1038/nature04924, 2006.

Rothman, L. S., Jacquemart, D., Barbe, A., Benner, D. C., Birk, M., Brown, L. R., Carleer, M. R., Chackerian Jr., C., Chance, K., Coudert, L. H., Dana, V., Devi, V. M., Flaud, J.-M., Gamache, R. R., Goldman, A., Hartmann, J.-M., Jucks, K. W., Maki, A. G., Mandin, J.-Y., Massie, S. T., Orphal, J., Perrin, A., Rinsland, C. P., Smith, M. A. H., Tennyson, J., Tolchenov, R. N., Toth, R. A., Vander Auwera, J., Varanasi, P., and Wagner, G.: The HITRAN 2004 Molecular Spectroscopic Database, J. Quant. Spectrosc. Ra., 96, 139-204, 2005.

Rothman, L. S., Gordon, I. E., Barbe, A., Benner, D. C., Bernath, P. F., Birk, M., Boudon, V., Brown, L. R., Campargue, A., Champion, J. P., Chance, K., Coudert, L. H., Dana, V., Devi, V. M., Fally, S., Flaud, J. M., Gamache, R. R., Goldman, A., Jacquemart, D., Kleiner, I., Lacome, N., Lafferty, W. J., Mandin, J. Y., Massie, S. T., Mikhailenko, S. N., Miller, C. E., Moazzen-Ahmadi, N., Naumenko, O. V., Nikitin, A. V., Orphal, J., Perevalov, V. I., Perrin, A., Predoi-Cross, A., Rinsland, C. P., Rotger, M., Simecková, M., Smith, M. A. H., Sung, K., Tashkun, S. A., Tennyson, J., Toth, R. A., Vandaele, A. C., and Vander Auwera, J.: The HITRAN 2008 molecular spectroscopic database, J. Quant. Spectrosc. Ra., 110, 533-572, 2009.

Schneider, M., Yoshimura, K., Hase, F., and Blumenstock, T.: The ground-based FTIR network's potential for investigating the atmospheric water cycle, Atmos. Chem. Phys., 10, 3427-3442, doi:10.5194/acp-10-3427-2010, 2010.

Schultz, M., Backman, L., Balkanski, Y., Bjoerndalsaeter, S., Brand, R., Burrows, J., Dalsoeren, S., de Vasconcelos, M., Grodtmann, B., Hauglustaine, D., Heil, A., Hoelzemann, J., Isaksen, I., Kaurola, J., Knorr, W., Ladstaetter-Weißenmayer, A., Mota, B., Oom, D., Pacyna, J., Panasiuk, D., Pereira, J., Pulles, T., Pyle, J., Rast, S., Richter, A., Savage, N., Schnadt, C., Schulz, M., Spessa, A., Staehelin, J., Sundet, J., Szopa, S., Thonicke, K., van het Bolscher, M., van Noije, T., van Velthoven, P., Vik, A., and 
Wittrock, F.: REanalysis of the TROpospheric chemical composition over the past 40 years - A long-term global modeling study of tropospheric chemistry, final report 48/2007, Max Planck Institute for Meteorology, Hamburg, Germany, 2007.

Street, J. O., Carroll, R. J., and Ruppert, D.: A Note on Computing Robust Regression Estimates via Iteratively Reweighted Least Squares, Am. Stat., 42, 152-154, doi:10.1080/00031305.1988.10475548, 1988.

Té, Y., Jeseck, P., Payan, S., Pépin, I., and Camy-Peyret, C.: The Fourier transform spectrometer of the UPMC University QualAir platform, Rev. Sci. Instrum., 81, 103102, doi:10.1063/1.3488357, 2010.

Té, Y., Dieudonné, E., Jeseck, P., Hase, F., Hadji-Lazaro, J., Clerbaux, C., Ravetta, F., Payan, S., Pépin, I., Hurtmans, D., Pelon, J., and Camy-Peyret, C.: Carbon monoxide urban emission monitoring: a ground-based FTIR case study, J. Atmos. Ocean. Tech., 29, 911-921, doi:10.1175/JTECH-D-11-00040.1, 2012.

Thompson, A. M.: The oxidizing capacity of the earth's atmosphere: Probable past and future changes, Science, 286, 11571165, doi:10.1126/science.256.5060.1157, 1992.

Thompson, A. M., Huntley, M. A., and Stewart, R. W.: Perturbations to tropospheric oxidants, 1985-2035: 1. Calculations of ozone and $\mathrm{OH}$ in chemically coherent regions, J. Geophys. Res, 95, 9829-9844, doi:10.1029/JD095iD07p09829, 1990.

Tournier, B., Blumstein, D., Cayla, F.-R., and Chalon, G.: IASI level 0 and 1 processing algorithms description, in: Proc. 12th Int. TOVS Study Conf. (ITSC-XII), 27 February-5 March 2002, Lorne, VIC, Australia, 2002.

van der Werf, G. R., Randerson, J. T., Giglio, L., Collatz, G. J., Mu, M., Kasibhatla, P. S., Morton, D. C., DeFries, R. S., Jin, Y., and van Leeuwen, T. T.: Global fire emissions and the contribution of deforestation, savanna, forest, agricultural, and peat fires (19972009), Atmos. Chem. Phys., 10, 11707-11735, doi:10.5194/acp10-11707-2010, 2010.

van Donkelaar, A., Martin, R. V., Leaitch, W. R., Macdonald, A. M., Walker, T. W., Streets, D. G., Zhang, Q., Dunlea, E. J., Jimenez, J. L., Dibb, J. E., Huey, L. G., Weber, R., and Andreae, M. O.: Analysis of aircraft and satellite measurements from the Intercontinental Chemical Transport Experiment (INTEX-B) to quantify long-range transport of East Asian sulfur to Canada, Atmos. Chem. Phys., 8, 2999-3014, doi:10.5194/acp-8-2999-2008, 2008.

Viatte, C., Schneider, M., Redondas, A., Hase, F., Eremenko, M., Chelin, P., Flaud, J.-M., Blumenstock, T., and Orphal, J.: Comparison of ground-based FTIR and Brewer $\mathrm{O}_{3}$ total column with data from two different IASI algorithms and from OMI and GOME-2 satellite instruments, Atmos. Meas. Tech., 4, 535-546, doi:10.5194/amt-4-535-2011, 2011.

Weinstock, B.: Carbon Monoxide: Residence Time in the Atmosphere, Science, 166, 224-225, 1969.

Worden, H. M., Deeter, M. N., Edwards, D. P., Gille, J. C., Drummond, J. R., and Nédélec, P.: Observations of nearsurface carbon monoxide from space using MOPITT multispectral retrievals, J. Geophys. Res.-Atmos., 115, D18314, doi:10.1029/2010JD014242, 2010.

Xiao, Y., Logan, J. A., Jacob, D. J., Hudman, R. C., Yantosca, R., and Blake, D. R.: Global budget of ethane and regional constraints on US sources, J. Geophys. Res., 113, 21306, doi:10.1029/2007JD009415, 2008.
Yurganov, L. N., Blumenstock, T., Grechko, E. I., Hase, F., Hyer, E. J., Kasischke, E. S., Koike, M., Kondo, Y., Kramer, I., Leung, F.-Y., Mahieu, E., Mellqvist, J., Notholt, J., Novelli, P. C., Rinsland, C. P., Scheel, H. E., Schulz, A., Strandberg, A., Sussmann, R., Tanimoto, H., Velazco, V., Zander, R., and Zhao, Y.: A quantitative assessment of the 1998 carbon monoxide emission anomaly in the Northern Hemisphere based on total column and surface concentration measurements, J. Geophys. Res.-Atmos., 109, D15305, doi:10.1029/2004JD004559, 2004.

Yurganov, L. N., Duchatelet, P., Dzhola, A. V., Edwards, D. P., Hase, F., Kramer, I., Mahieu, E., Mellqvist, J., Notholt, J., Novelli, P. C., Rockmann, A., Scheel, H. E., Schneider, M., Schulz, A., Strandberg, A., Sussmann, R., Tanimoto, H., Velazco, V., Drummond, J. R., and Gille, J. C.: Increased Northern Hemispheric carbon monoxide burden in the troposphere in 2002 and 2003 detected from the ground and from space, Atmos. Chem. Phys., 5, 563-573, doi:10.5194/acp-5-563-2005, 2005.

Zander, R., Demoulin, P., Ehhalt, D. H., Schmidt, U., and Rinsland, C. P.: Secular increase of the total vertical column abundance of carbon monoxide above central Europe since 1950, J. Geophys. Res.-Atmos., 94, 11021-11028, doi:10.1029/JD094iD08p11021, 1989.

Zander, R., Mahieu, E., Demoulin, P., Duchatelet, P., Roland, G., Servais, C., Mazière, D. M., Reimann, S., and Rinsland, C. P.: Our changing atmosphere: Evidence based on long-term infrared solar observations at the Jungfraujoch since 1950, Sci. Total Environ., 391, 184-195, doi:10.1016/j.scitotenv.2007.10.018, 2008.

Zbinden, R. M., Thouret, V., Ricaud, P., Carminati, F., Cammas, J.P., and Nédélec, P.: Climatology of pure tropospheric profiles and column contents of ozone and carbon monoxide using MOZAIC in the mid-northern latitudes $\left(24^{\circ} \mathrm{N}\right.$ to $\left.50^{\circ} \mathrm{N}\right)$ from 1994 to 2009, Atmos. Chem. Phys., 13, 12363-12388, doi:10.5194/acp13-12363-2013, 2013.

Zellweger, C., Hüglin, C., Klausen, J., Steinbacher, M., Vollmer, M., and Buchmann, B.: Inter-comparison of four different carbon monoxide measurement techniques and evaluation of the long-term carbon monoxide time series of Jungfraujoch, Atmos. Chem. Phys., 9, 3491-3503, doi:10.5194/acp-9-3491-2009, 2009.

Zeng, G., Williams, J. E., Fisher, J. A., Emmons, L. K., Jones, N. B., Morgenstern, O., Robinson, J., Smale, D., Paton-Walsh, C., and Griffith, D. W. T.: Multi-model simulation of $\mathrm{CO}$ and $\mathrm{HCHO}$ in the Southern Hemisphere: comparison with observations and impact of biogenic emissions, Atmos. Chem. Phys., 15, 72177245, doi:10.5194/acp-15-7217-2015, 2015.

Zhao, Y., Kondo, Y., Murcray, F. J., Liu, X., Koike, M., Kita, K., Nakajima, H., Murata, I., and Suzuki, K.: Carbon monoxide column abundances and tropospheric concentrations retrieved from high resolution ground-based infrared solar spectra at $43.5^{\circ} \mathrm{N}$ over Japan, J. Geophys. Res., 102, 23403-23411, 1997.

Zhao, Y., Strong, K., Kondo, Y., Koike, M., Matsumi, Y., Irie, Y., Rinsland, H., C, P., Jones, N. B., Suzuki, K., Nakajima, H., Nakane, H., and Murata, I.: Spectroscopic measurements of tropospheric $\mathrm{CO}, \mathrm{C}_{2} \mathrm{H}_{6}, \mathrm{C}_{2} \mathrm{H}_{2}$ and $\mathrm{HCN}$ in Northern Japan, J. Geophy. Res., 107, 4343, doi:10.1029/2001JD000748, 2002. 